\title{
Mathematical model of water absorption area in intensive garden irrigation from the ground
}

\author{
Fazliddin Juraev ${ }^{1 *}$, and Galib Karimov \\ Bukhara Branch of the Tashkent Institute of Irrigation and Agricultural Mechanization Engineers, \\ Bukhara, Uzbekistan
}

\begin{abstract}
This article presents the results of field experiments to irrigate intensive gardens, located in water-scarce areas, from the soil with special piles. Experiments were conducted in Kagan district of Bukhara region in 2016 to determine the optimal procedure for in-soil irrigation of apple variety "Pinc lady" in the intensive orchard, established in 2016 at the farm "Siyavush Kamron FOOD" in cooperation with Turkey. In this case, a mathematical model was developed to determine the irrigation area corresponding to the radius of propagation of the roots of three-year-old trees and to calculate water consumption. This makes it possible to determine the norms of irrigation of intensive garden trees.

This method can be used to set half scrubby intensive gardens in such areas where water is insufficient and use energy-saving technologies in the future.
\end{abstract}

\section{INTRODUCTION}

The world uses 2.8 thousand $\mathrm{km}^{3}$ of fresh water per year for agricultural purposes, which is $70 \%$ of total freshwater consumption. According to the International Commission on Irrigation and Drainage, the world's irrigated area is estimated at 299,488 million hectares. Also, 40 percent of food and 60 percent of cereals are obtained from irrigated land. One of the urgent issues in the effective use of water resources in the country is the development of science-based irrigation procedures for gardens and water-saving irrigation technologies that implement them $[1,2]$.

The following scientific results have been obtained based on world research on high and sustainable yields of agricultural crops on irrigated lands: Technologies for a timely and optimal supply of water for irrigation (Food and Agriculture Organization of the United Nations, Institute of Cotton Research); developed science-based irrigation regimes in crop irrigation to maintain water-nutrient-air-salt-heat balance (Australian Cotton Research Institute); developed water-saving irrigation technologies for irrigation of agricultural crops (Stockholm Technology University, Agriculture Academy of Bulgaria); high and sustainable yields, efficient use of water resources (International Water Management Institute); the impact of the use of different irrigation technologies on soil water-physical properties, reclamation status and fertility has been identified (Indian Agricultural Research Institute, Tamil Node Agricultural University) [3-8].

*Corresponding author: fjuraev66@mail.ru 
Efficient use of available water resources in irrigated agriculture requires the implementation of water distribution based on crop demand, scientific research on irrigation procedures, and technologies of crops. The world's leading research institutes, research centers, and higher education institutions, including the Food and Agriculture Organization of the United Nations (FAO), the Institute of Cotton Research (ICR, CAAS), the Australian Cotton Research Institute (Australia), Stockholm Technology University (Sweden), Agriculture Academy of Bulgaria (Bulgaria), International Water Management Institute (Sri Lanka), Indian Agricultural Research Institute, Tamil Node Agricultural University (India), A.N. Kostyakov Research Institute, on plant phases studied the demand for water and the shape and size of wetting areas in irrigation methods.

In research, many scientific publications have been published by scientists on the problems of mathematical modeling of hydro-physical processes of soil moisture permeability: Aleksashenko A.A. [9], Axmedova A.D. [10], Brovtsina V.N. [11], Bedanokovoy S.Yu. [12,13], Gostishcheva D.P. [14], Golovanova A.I. [15], Grigorova S.M. [16], Dobracheva Yu.P. [17,18], Shkury V.N. [19], Mykayylova F. [20].

Numerous scientific articles on the cost-effectiveness of water-saving technologies of intensive garden irrigation and the impact on soil reclamation have been published by Uzbek scientists: Baraev FA [21], Gulomov S.B. [22], Baraev F.A., Serikbaev B.S. [23], M. Sarimsaqov [24], F.U. Jurayev, G.H.Karimov [25]. Theoretical and experimental studies on drip irrigation and soil irrigation systems have not been sufficiently studied in relation to the movement of solutes in irrigation water (including fertilizers) in isothermal unsaturated environments, i.e., the shape and size of wetting areas in the soil. This is especially relevant today due to the increasing use of wastewater for irrigation and the fight against environmental pollution.

\section{Methods}

Scientific studies have shown that the processes of moisture transfer in the soil under medium sandy soils due to the alluvial, mechanical composition of the meadow have not been sufficiently studied. The laws of contour formation of moisture areas in irrigation make it possible to predict the parameters of moisture transfer by substantiating a mathematical model of the dynamics of moisture distribution. Problems of drip irrigation and soil irrigation, engineering calculations of equipment, and optimization of parameters of irrigation regimes were studied. The results obtained by various researchers show typical approximations of the contours of the moisture distribution areas. This shows the configuration options of the isopleth area Moisture in drip irrigation for different soil types studied by Russian scientists: O.E. Yasonidi, L.G., B.B. Shumakov, Dudnikovoy, M.I. Romashchenko, A.V. Shuravilinym, O.N. Karpenko, A.D. Axmedovym, M.Yu. Xrabrovym, V.V. Borodychevym, V.S. Bocharnikov, D.O. Zavadskim [20].

Summarizing the above studies, the moisture contours can be visualized in the following view in terms of the complexity of the model, the type of configuration, and the geometric representation of the spatial area description. 


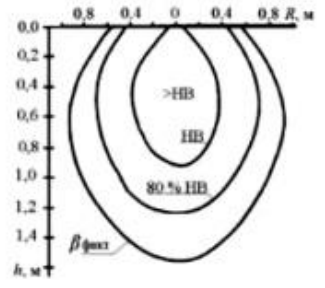

1)

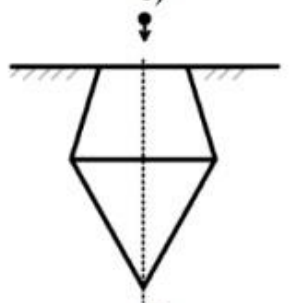

4)

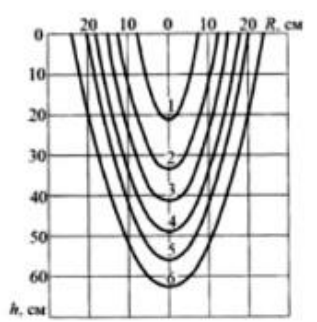

2)

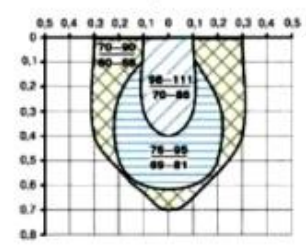

5)

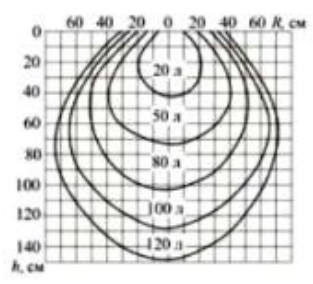

3)

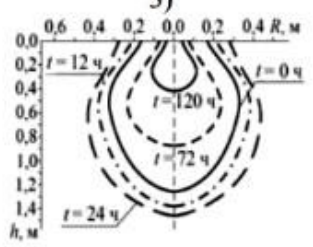

6)

Fig. 1. The area formed by the water absorption limit in the soil composition is given in Table 1 by type of spatial gura

Table 1.Classification of wetting configurations in drip irrigation

\begin{tabular}{|c|c|c|c|}
\hline Group & $\begin{array}{c}\text { Type of spatial } \\
\text { configuration }\end{array}$ & Geometric model & Numbers \\
\hline \multirow{3}{*}{ Simple } & Ellipsoid & (circle cut ellipsoid) & 1 ) \\
\cline { 2 - 4 } & Parabolic & (rotation paraboloid) & 2 ) \\
\cline { 2 - 4 } & Spherical & (cut ball) & 3 ) \\
\hline \multirow{3}{*}{ Combined: } & Cone-shaped & Cut Cone + Cone & 4 ) \\
\cline { 2 - 4 } & Cone-cylinder & Cylinder + cone & 5) \\
\cline { 2 - 4 } & Cone-hyperbolic & $\begin{array}{c}\text { Cut cone + circle } \\
\text { hyperboloid }\end{array}$ & ( \\
\hline
\end{tabular}

Various models for determining the wetting areas of water entering the soil during drip irrigation have been developed and studied based on the spatial forms shown in Table 1 above [26-28].

\section{Results and Discussion}

In the Kagan district of the Bukhara region, in 2016, an intensive orchard was established at the Siyavush Kamron FOOD farm, established in cooperation with Turkey. In the Kagan district of the Bukhara region, in 2016, an intensive orchard was established at the "Siyavush Kamron FOOD" farm, established in cooperation with Turkey. Experiments were conducted to determine the optimal irrigation regime for Pinc Lady apple.

Field experiments were carried out in the conditions of the alluvial, mechanical composition of meadow sandy soils with a groundwater level of 1.5-2.0 m, mineralization of 1.0-1.2 g,1. Based on the data obtained on soil salinity, the field characteristics of the experimental field were as follows: the chlorine-ion content was $0.003 \%$ when the dry residue content was $0.05-0.09 \%$ - high carbonate in profile, no gypsum. Humus in the plowed layer is characterized by an average porosity of $1.29-1.73 \%$ and soil content of $50.8-51.9 \%$. 
Although pre-irrigation irrigation is used to irrigate apple orchards, it is recommended to use drip irrigation as the most effective irrigation method. It is also recommended to use sprinkler irrigation to create microclimate conditions in regions with hot climates, and it gives good results. When dripping irrigation of apple orchards, it is recommended to install one watering hose in each row of trees and 1 or 2 drips next to each (young) tree. When installing two drips, the distance between them should be $0.6-1.0$ meters (distance from the trunk $0.3-0.6$ meters). Drip irrigation is not considered an effective irrigation system suitable for any climatic conditions. There are also disadvantages of drip irrigation in desert areas where climatic conditions are changing, i.e., very hot in summer[28-30].

The specificity of an in-soil irrigation system is determined because it consists of a permanent network of pressurized water distribution. This network delivers normal water continuously and regularly to the root system layers of seedlings directly with a moderate amount of fertilizer mixture. There are the following technical and design elements and parameters of the technology of irrigation through the piles from the soil: 1 to 2 (depending on age) piles are installed around the apple seedlings; the length of the pegs is $50 \mathrm{~cm}, 60$ $\mathrm{cm}, 70 \mathrm{~cm}$ is selected depending on the volumetric width of the tree root; water consumption of each pile is 2.5-3.2 liters, hour; the working pressure in the system is 1.5$2.5 \mathrm{~m}[9,10]$.

The water consumption of the piles is usually selected depending on the water permeability of the soil. The type of soil also determines the period between irrigations, and in the hot climate of Bukhara, it is recommended to irrigate every 2-3 days. To determine the optimal irrigation regime, it is necessary to determine the area of irrigation while knowing the information about the area of root propagation of seedlings. Table 2 shows the wetting area of a single pile during in-soil irrigation [31-34].

Table 2. Soil moisture indicators in drip irrigation of fruit trees

\begin{tabular}{|c|c|c|c|c|c|}
\hline & \multirow{2}{*}{$\begin{array}{c}\text { Depth of } \\
\text { propagation of } \\
\text { the main part of } \\
\text { the roots, } \mathrm{m}\end{array}$} & $\begin{array}{c}\text { Dining } \\
\text { area, } \mathrm{m}^{2}\end{array}$ & $\begin{array}{c}\text { Depth, } \\
\text { (h) } \mathrm{m}\end{array}$ & $\begin{array}{c}\text { Humidification } \\
\text { contour area, } \\
\mathrm{m}^{2}\end{array}$ & $\begin{array}{c}\text { Moisturized } \\
\text { part of the } \\
\text { feeding area, } \\
\text { percentage } \\
\left(\mathrm{K}_{\mathrm{k}}\right)\end{array}$ \\
\hline 1- sample & $0.6-0.9$ & $3-7$ & $0.8-1.0$ & $2-6$ & $0.1-0.3$ \\
\hline 2- sample & $0.7-1.0$ & $4-8$ & $0.6-0.8$ & $2-5$ & $0.1-0.2$ \\
\hline 3- sample & $0.5-0.8$ & $4-7$ & $0.7-0.9$ & $3-6$ & $0.1-0.2$ \\
\hline
\end{tabular}

The development of various issues of mathematical modeling of land reclamation will be the basis for the development, optimization, and development of certain types of irrigation. In intensive gardens, the physicochemical properties of soils, hydro-ameliorative conditions, and applied agro-ameliorative techniques and technologies were considered.

Based on the results of research on the efficient use of water resources in irrigated agriculture, the optimal order of irrigation of gardens, the development of water-saving irrigation technologies that implement it:

- mathematical models developed in the form of partial systems, methods of computer research and optimization of parameters of wet transfer processes taking into account differential equations and hydrophysics, soil properties;

- mathematical and statistical characteristics of irrigation, mechanical properties of soils, geometric characteristics of the boundaries of wetting zones, ensuring the optimality of technological parameters during irrigation; 
The results of the evaluation of economic and agro-energy efficiency and the creation of a system that allows optimizing the allocation of resources through the creation of a model of optimization of irrigation of intensive gardens.

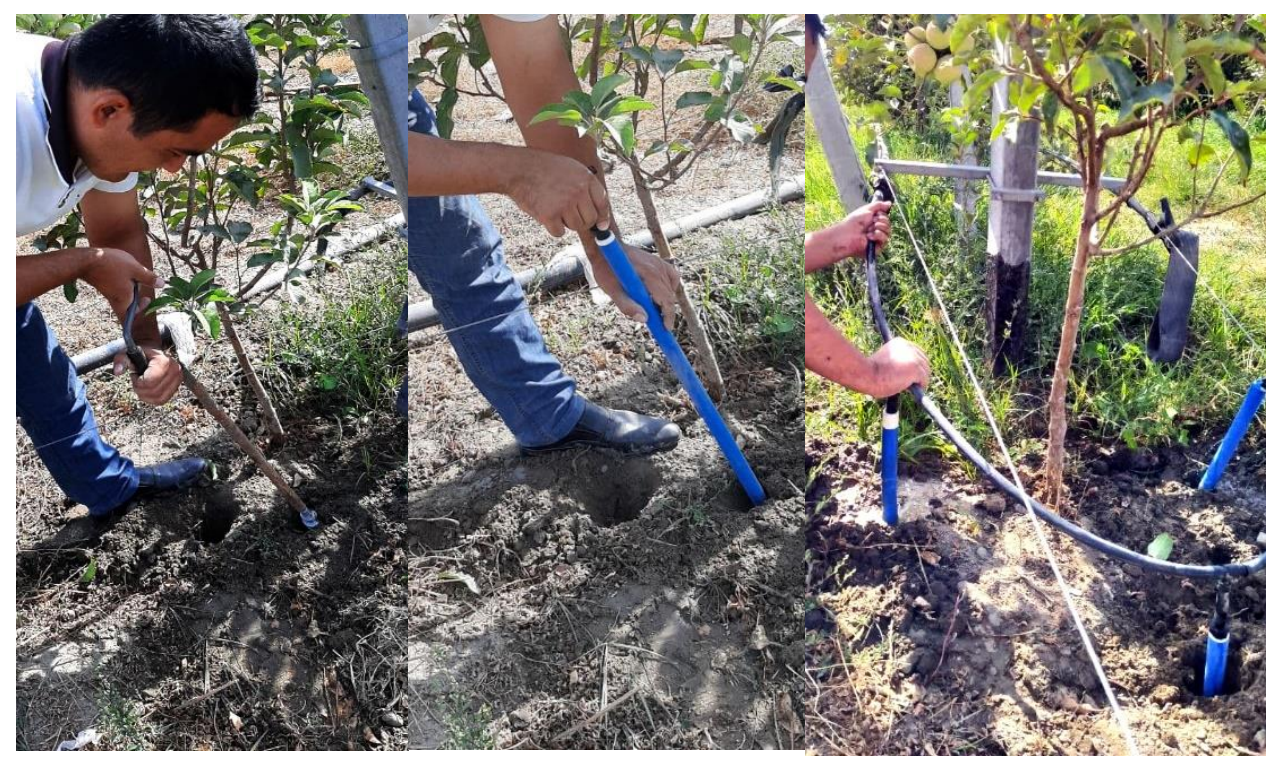

Picture 1. Learning "Golden delicious" scrubby apple seedlings root system

In the study, we determine the contours of the wetting area based on lines delimiting the wetting area on the values of geometric parameters, using the graph analytic method to determine the contours of wetting in subsoil irrigation.

$$
\begin{gathered}
\left(d_{\text {max }} / h_{\text {max }}\right)_{W_{g / \text { hour }}}=0.51+0.009 \cdot W_{g / \text { hour }} \\
\left(d_{\text {max }} / h_{\text {max }}\right)_{W_{n v}}=0.51+0.009 \cdot W_{n v} \\
\left(d_{\text {max }} / h_{\text {max }}\right)_{V_{c n}}=0.924 \cdot(\bar{V})_{1 \text { hour }}
\end{gathered}
$$

where $h_{k о \mathrm{H}}$-is the depth of the moisture contour, m; $d_{k \mathrm{H}}$-the calculated diameter of the contour corresponding to its maximum value, $\mathrm{m}$; $d_{\text {pov }}$ - is the diameter of the contour at the level of penetration into the soil layer of $5 \mathrm{~cm}$, or "surface diameter", $\mathrm{m}$. 


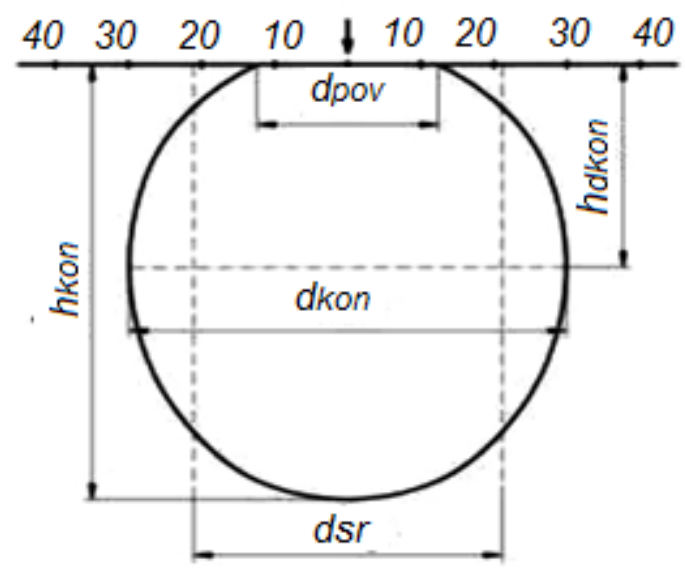

Fig.2. shows the shape-appropriate shape of the proposed soil-based irrigation device for the soil wetting area.

However, to model water use efficiency,

$$
\ni_{\text {vod }}=\frac{C B}{B_{m}}
$$

where $C B$ is dry soil mass, $\mathrm{kg} ; B_{m}$ is the mass of water involved in transpiration, $\mathrm{kg}$

For some plant species (species), $\ni_{\text {vod }}$ is usually close to 0.0016 ; for some species, it is twice as large, about 0.0032 . The calculation of the total water consumption in the model used is calculated using the Penmana-Monteifa formula [21].

Let $E$ be the amount of evaporation per unit area of the plant surface; let's define the transpiration intensity as $\mathrm{kg} / \mathrm{m}^{2}$. The Penmana-Monteifa formula can be expressed as follows.

$$
\mathrm{E}=\frac{s A+c_{p} \rho\left[p_{s}\left(T_{a}\right)-p_{a}\right] g_{a}}{\lambda\left[s+\gamma\left(1+\frac{g_{a}}{g_{c}}\right)\right]}
$$

The psychrometric constant $\gamma$ is determined from the total atmospheric pressure $\mathrm{P}, \mathrm{Pa}$, based on formula (3).

$$
\gamma=\frac{c_{p} P}{\lambda \varepsilon}
$$

where $\varepsilon=0.622$ is water vapor is obtained relative to the molecular weight of air.

In the applied model, the calculation formula for the total water consumption was calculated using the Penmana-Monteifa formula. In this case, the following evapotranspiration for the formula (3) in the practical calculations for the creation of a mathematical model of the moisture distribution of irrigation water in the soil is determined in the form $\mathrm{ET}_{0}, \mathrm{~mm} /$ day.

$$
E T_{0}=\frac{0.408 \Delta\left(R_{n}-G\right)+\gamma \frac{900}{t+273} U_{2}\left(e_{s}-e_{a}\right)}{\Delta+\gamma\left(1+0.34 U_{2}\right)}
$$

An assessment of the need for water is required to design an irrigation regime. The soil moisture deficit $S_{d}$ was defined as the volume of water $\left(\mathrm{m}^{3}\right)$ per unit area. The variables can 
be determined by denoting the amount of precipitation $R$, the amount of water evaporation $E_{v}$ and the amount of water supplied $L$, in the form [22]:

Here $S_{d}>0$ or $R<E_{v}$

$$
\begin{gathered}
S_{d}=S_{d}(t=0)-\int\left(E_{v}-R\right) d t \text { and } L=0 \\
\quad S_{d}>0 \text { and } R \geq E_{v} \\
L=R-E_{v}
\end{gathered}
$$

$E_{v}$ value is determined depending on the actual transpiration.

$$
E_{v}=E_{n o m}\left(1-\beta S_{d}\right)
$$

where $\beta$ is the continuity.

For example, the limit $S_{d}$ corresponding to the decrease in humidity is determined in the following case:

$$
\begin{gathered}
S_{d} \leq S_{d \text { parog }} E_{v}=E_{n o m} \\
S_{d} \leq S_{d \text { parog }} E_{v}=E_{\text {nom }}\left\{1-\beta\left[S_{d}-S_{\text {d parog }}\right]\right\}
\end{gathered}
$$

The formulas describing the moisture transfer models can be divided empirically and semi-empirically.

A group of empirical models is a group of mathematical models built on the basis of experimental data related to a specific local object. During the construction of the model, the size of the empirical data sample that determines its adequacy is important. In general, empirical (regression) models can be written as follows.

$$
\hat{y}=f\left(a_{1}, a_{2}, \ldots, a_{m}, x_{1}, x_{2}, \ldots, x_{p}\right)
$$

Where $\hat{y}$ is the characteristic under study (related or explained variable), $x_{i}$ is the factor (independent or explanatory variable), $a_{j}$ is the required coefficients, $p$ is the total number of factors analyzed [23-27].

$$
\begin{gathered}
\hat{y}=\sum_{i=0}^{m} a_{i} \varphi_{i}(x) \\
\hat{y}=\sum_{i=0}^{m} a_{i} \varphi_{i}\left(x_{1}, x_{2}, \ldots, x_{p}\right)
\end{gathered}
$$

where $\varphi_{i}$ is a free variable function.

The formula for calculating the total water consumption in the applied model is in the electronic determination of the water distribution area of a single pile per unit time using the Penmana-Monteifa formula. The experiments were performed on the following systems. The mechanical composition of the soil of the experimental field belongs to the type of soils with a mechanical composition of medium sand according to the description of N.A. Kachinsky. 

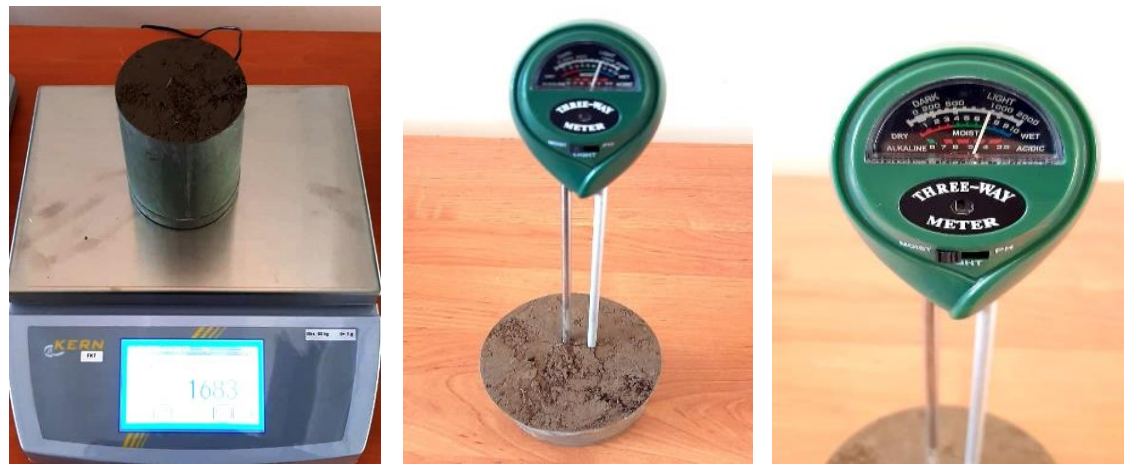

Pic. 2.

Thus, one of the important tasks of land reclamation is the development of new progressive methods and techniques of irrigation (Picture 2.), including based on mathematical modeling. These methods provide irrigated areas with strictly standardized water, its efficient use.

\section{Conclusions}

Scientific research on the efficient use of water resources has been carried out in the following areas of inland irrigation: determining the optimal irrigation regime for gardens; water consumption of the irrigation device; the degree of wetting of the area where the water is coming out of the device is located; the effect of inland irrigation on groundwater and soil reclamation was studied. Improving calculations using empirical formulas in the theoretical determination of water consumption of plants; on the basis of mathematical modeling of the wetting area in in-soil irrigation, to achieve optimal standardized water supply of garden areas, to determine the optimal terms and standards, taking into account the development of methods that allow its efficient use.

\section{Acknowledgements}

The proposed irrigation technology is the latest science-based innovation in water-saving technology, the organization of intensive irrigation of gardens from the ground, which has a positive effect on its application. Currently, in the agricultural conditions of Uzbekistan: surface (surface) irrigation; sprinkler irrigation; irrigation from the soil; irrigation technologies such as drip irrigation have been used. It is taking into account some of the shortcomings of the above-mentioned irrigation system, intensive irrigation of gardens from the ground, water-saving, i.e., meeting the plant's demand for water with low water consumption, not using too much water, preventing water evaporation.

Researchers have proven that in-soil irrigation can reduce water consumption by 2-3 times compared to surface irrigation. In intensive gardens, rows of seedlings prevent the growth of weeds; water-soluble mineral fertilizers are applied directly to the root system, creating conditions for normal growth and development of seedlings, harvesting, as well as preventing them from various diseases.

\section{References}

1. Aleksashenko, A.A. Teoreticheskie voprosy kapelnogo orosheniya, A.A. Aleksashenko, N.I.Vdovin, Vestnik s.-x. nauki. (8). pp.10-14. (1977)

2. Axmedov, A.D. Dynamics of soil moisture during drip irrigation of gardens, A.D. Axmedov, A.A. Temerev, E.Yu. Galiullina, Izvestiya Nizhnevoljskogo 
agrouniversitetskogo kompleksa: nauka i vysshee professionalnoe obrazovanie. 2 (22). pp. 159-164. (2011)

3. Brovtsin, V.N., Popov A.A. Otsenka teplovlajnostnyx rejimov v profilirovannoy pochve metodom vыchislitelnogo eksperimenta, Texnologii i tehnicheskie sredstva mekhanizirovannogo proizvodstva produktsii rastenievodstva i jivotnovodstva, (87). pp. 151-163. (2015)

4. Bedanokova, S. Yu. Matematicheskoe modelirovanie solevogo rejima pochv $\mathrm{s}$ fraktalnoy strukturoy, Vestn. Sam. gos. techn. un-ta. Ser. Phys.-mat. Nauki. 2 (15). pp. 102-109. (2007)

5. Bedanokova, S.Yu. Zadacha Koshi i nelokalnaya kraevaya zadacha dlya obobshchënnyx drobnyx ostsillyatsionnyx uravneniy, S.Yu. Bedanokova, Dokl. Adyg. (Circassian.) Mejdunar. acad. Science. 8. (1). pp. 9-15. (2005)

6. Gostishchev, D.P. Matematicheskoe modelirovanie vlagoperenosa pri VPO, D.L. Gostishchev, D.S. Valiev, Evraziyskoe Nauchnoe Ob'edinenie. 3 (15). pp. 165-171. (2016)

7. Golovanov, A.I., Vzaimosvyaz mezhdu plodorodiem pochv i vodnym regime pri vyrashchivanii kartofelya na dernovo-podzolistyx pochvax, A.I. Golovanov, V.V. Pchelkin, V.O. Gerasimov, O.M. Kuzina, Nauchnaya jizn. (6). pp. 85-94. (2018)

8. Grigorov, M.S. Osobennosti peredvijeniya vlagi v pochve pri vnutripochvennom oroshenii, M.S. Grigorov, A.D. Axmedov. - 296 journals of agrarian science. (5). p. 15. (2005).

9. Dobrachev, Yu.P. Method of obosnovaniya obespecheniya vodnymi resursami obektov gidromelioratsii pri razrabotke SKIOVO, Yu.P. Dobrachev, A.L. Buber, L.V. Kireycheva et al. V sborn .: Kompleksnye melioratsii - sredstvo povysheniya produktivnosti selskoxozyaystvennyx zemel. - FGBNU VNIIGiM im. A.N.Kostyakova. pp. 54-66. (2014)

10. Dobrachev, Yu.P. Models rosta i razvitiya rasteniy i zadacha povыsheniya urojaynosti,Yu.P. Dobrachev, A.L.Sokolov , Prirodoobustroystvo. 3. pp. 90-96. (2016)

11. Shkura, V.N. About uchete pochvennyx vodno-fizicheskix characteristic at determining parameters of contour kapelnogo uvlajneniya pochvy,V.N. Shkura, A.S. Shtanko, Nauchnыy magazine Rossiyskogo NII problem melioratsii. 4 (28). pp. 137153. (2017)

12. Shkura, V.N. About uchete pochvennyx vodno-fizicheskix characteristic at determining parameters of contour kapelnogo uvlajneniya pochvy,V.N. Shkura, A.S. Shtanko, Nauchnыy magazine Rossiyskogo NII problem melioratsii. 4 (28). pp. 137153. (2019)

13. Baraev FA, Gulomov SB, "Application of drip irrigation technology in horticulture", "Agriculture of Uzbekistan". -Tashkent, 12. pp. 38-39. (05.00.00; №8). (2015)

14. Baraev F.A., Serikbaev B.S., Gulomov S.B., "Reliability of drip irrigation system", "IRRIGATION and MELIORATSIA" magazine. Toshkent 2017. 4 (10). B. 10-12. (05.00.00; №22). Tashkent-2011. 1-2. pp. 116-118. (2017)

15. Sarimsakov.M., "Selection of elements of irrigation methods and techniques in intensive gardens" Bulletin "Ecology". Tashkent, 9. pp. 37-39 (2019)

16. F.U. Jurayev, G.H.Karimov. Organization of drip irrigation in desert areas. AGRO ILM. Journal of agrarian and economic science. 6 (38) .pp. 48-49. (2015)

17. Shkura, V.N. About uchete pochvennyx vodno-fizicheskix characteristic at determining parameters of contour kapelnogo uvlajneniya pochvy, V.N. Shkura, A.S. Shtanko, Nauchnыy magazine Rossiyskogo NII problem melioratsii. 4 (28). pp. 137153. (2015)

18. Shtanko, A. S. Otsenka tochnosti approksimatsii polojeniya isoplet 322 lokalnyx 
konturov uvlajneniya pri kapelnom polive, A. S. Shtanko, Yu. Yu. Glushchenko, O. V. Voronov, Scientific journal Rossiyskogo NII problem melioratsii [Electronic resource].. 2 (26). pp. 69-86. Access mode:

19. Shtanko, A.S. Vnutrikonturnoe raspredelenie vlajnosti pochvы pri kapelnom oroshenii, A.S. Shtanko, V.N. Shkura, Nauchnыy magazine Rossiyskogo NII problem melioratsii. 4 (28). pp. 62-78. (2017)

20. Shtanko, A.S. Sposob grafoanaliticheskogo postroeniya ochertaniya konturov kapelnogo uvlajneniya pochv, A.S. Shtanko, V.N. Shkura, Nauchnby magazine Rossiyskogo NII problem melioratsii. 1 (29). pp. 67-85. (2018)

21. Frans, Dj., Matematicheskie modeli v selskom khozyaystve, Dj. Frans, Dj.X.Tornley. - M .: Agropromizdat,. p 400. (1987)

22. Khamidov, M.K., Khamraev, K.S., Isabaev, K.T. Innovative soil leaching technology, A case study from Bukhara region of Uzbekistan. IOP Conference Series: Earth and Environmental Science, (1), p 422. 012118. (2020)

23. Khamidov, M., Matyakubov, B., Isabaev, K. Substantiation of cotton irrigation regime on meadow-alluvial soils of the Khorezm oasis. Journal of Critical Reviews, 7(4), pp. 347-353. (2020).

24. Khamidov, M., Khamraev, K., Azizov, S., Akhmedjanova, G. Water saving technology for leaching salinity of irrigated lands. A case study from Bukhara region of Uzbekistan. Journal of Critical Reviews, 7(1), pp. 499-509, (2020).

25. Balla, D., Omar, M., Maassen, S., Hamidov, A., Khamidov, M. Efficiency of duckweed (Lemnaceae) for the desalination and treatment of agricultural drainage water in detention reservoirs. Environmental Science and Engineering (Subseries: Environmental Science), (202979), pp. 423-440. (2014)

26. Matyakubov B. How efficient irrigation can ensure water supply in the Lower Amudarya basin of Uzbekistan, . International Water and Irrigation, 23 (3), pp. 26-27. (2003).

27. Uralov B., Xidirov S., Matyakubov B., Eshonkulov Z., Norkulov B., Gayur A. "River channel deformations in the area of damless water intake", FORM-2020, IOP Publishing, IOP Conf. Series: Materials Science and Engineering 869 (2020) 072014., doi:10.1088/1757-899X/869/7/072014 .

28. Bazarov D., Uralov B., Matyakubov B., Vokhidov O., Uljaev F., Akhmadi M. "The effects of morphometric elements of the channel on hydraulic resistance of machine channels of pumping stations", IOP Conference Series: Materials Science and Engineering, (2020).

29. Matyakubov B., Begmatov I., Raimova I., Teplova G. "Factors for the efficient use of water distribution facilities", CONMECHYDRO - 2020, IOP Conf. Series: Materials Science and Engineering 883 (2020) 012050 doi:10.1088/1757-899X/883/1/012050.

30. Matyakubov B., Mamazhonov M., Teplova G, Shakirov B., Shakirov B. "Forebays of the poligonal cross - section of the irrigating pumping station", CONMECHYDRO 2020, IOP Conf. Series: Materials Science and Engineering 883 (2020) 012050 doi:10.1088/1757-899X/883/1/012050.

31. Matyakubov B., Begmatov I., Mamataliev A., Botirov S., Khayitova M. "Condition of irrigation and drainage systems in the Khorezm region and recommendations for their improvement", Journal of Critical Reviews, ISSN- 2394-5125, 7, (5), pp. 417 - 421. (2020)

32. Matyakubov B.Sh., Mamatkulov Z.J., Oymatov R.K., Komilov U.N., Eshchanova G. "Assessment of the reclamation conditions of irrigated areas by geospatial analysis and recommendations for their improvement" , InterCarto. InterGIS GI SUPPORT OF SUSTAINABLE DEVELOPMENT OF TERRITORIES Proceedings of the International conference. 26. pp. 229 - 239. (2020), 
33. Begmatov I.A., Matyakubov B.Sh., Akhmatov D.E., Pulatova M.V. Analysis of saline land and determination of the level of salinity of irrigated lands with use of the geographic information system technologies, InterCarto. InterGIS GI SUPPORT OF SUSTAINABLE DEVELOPMENT OF TERRITORIES Proceedings of the International conference. 26. pp. 309 - 316. (2020),

34. Rahmatov Mahmud, Matyakubov Bakhtiyar, Berdiev Mustafo. "Maintainability of a self-pressurized closed irrigation network", IOP Conference Series: Materials Science and Engineering, 1030 (2021) 012170 IOP Publishing doi:10.1088/1757$899 X / 1030 / 1 / 012170$ 